\title{
Prevalence of Nematodiasis in Omasum and Abomasum of Goats Slaughtered at Pegirian Surabaya Slaughter House Through Gatrointestinal Surgery Method
}

\author{
Prevalensi Nematodosis pada Lambung (Omasum dan Abomasum) Kambing yang \\ dipotong di RPH Pegirian Surabaya Menggunakan Metode Bedah Saluran Pencernaan
}

\author{
${ }^{1)}$ Dewi Mariyam, ${ }^{2)}$ Sri Mumpuni Sosiawati, ${ }^{3)}$ Kuncoro Puguh Santoso, ${ }^{2)}$ Setiawan \\ Koesdarto, ${ }^{4)}$ Sarmanu, ${ }^{5}$ Ira Sari Yudaniayanti \\ ${ }^{1)}$ Mahasiswa, ${ }^{2}$ Departemen Parasitolgi Veteriner, ${ }^{3)}$ Departemen Kedokteran Dasar Veteriner, \\ ${ }^{4)}$ Departemen Anatomi Veteriner, ${ }^{5}$ Departemen Klinik Veteriner. Fakultas Kedokteran Hewan, \\ Universitas Airlangga.
}

\begin{abstract}
The purpose of this research is to determine the kind of nematodes and to determine the prevalence result. Thirtysix samples of omasum and abomasum were collected from RPH Pegirian from September-November 2017 then using gastrointestinal surgery to get fresh adult worm, afterwards using Semichen-Acetic Carmine stainning method to makes the object easy to microscopic identify. The result showed that species was found Haemonchus contortus, as an identify result show that adult worm has a character on a anterior part called cervical papilae, female worm has a barber's pole on body also posterior part has a vulva flap, posterior part of male worm has a bursa copulatrix, spicula, gubernaculum and dorsal rays looks like Y shape. Seventeen positive samples and the prevalence rate was 47,2\%, 273 adult worms and female worms $215(78,75 \%)$ and the male worms $58(21,25 \%)$. Chi-Square statistical test ( $\mathrm{P}$ $<0.05$ ) showed that 13 positive samples of kambing kacang (65\%) were higher infected Haemonchosis infection than 4 potitive samples of PE (25\%).
\end{abstract}

Keywords : prevalence, gastrointestinal surgery, goat, Pegirian Surabaya Slaughter House

\section{Pendahuluan}

Kambing adalah ternak ruminansia kecil yang paling dominan di Indonesia, akhir-akhir ini penggemukan kambing mulai marak dan menuntut peternak kambing sebagai penyedia bibit yang tumbuh cepat dan mencapai bobot potong pada usia muda selain itu terdapat beberapa keunggulan antara lain: (1) membutuhkan modal yang relatif kecil; (2) mudah pemeliharaannya; (3) multiguna (4) mudah dijual ketika membutuhkan uang kontan (Chalid dkk, 2011). Infeksi cacing saluran pencernaan menjadi salah satu penyebab rendahnya produksi daging ternak. Soulsby (1986), parasit pada saluran pencernaan kambing dapat mengganggu kesehatan hingga kematian. Terdapat 4 spesies cacing nematoda yang menginfeksi abomasum dan omasum kambing, yaitu Trichostrongylus axei, Cooperia sp (C. punctata, C. pectinata, C. oncophora, C. curticei), Haemonchus contortus, Mecistocirrus digitatus (Beriajaya dan D. B Copeman 1997).

Akibat utama yang ditimbulkan infeksi Nematoda pada omasum dan abomasum adalah kerusakan pada mukosa. Selain itu, selaput lendir dapat mengalami peradangan terdapat bentukan nekrosis pada permukaan organ (Levine, 1990).

Rumah Potong Hewan (RPH) Pegirian Surabaya, merupakan tempat pemotongan hewan terutama ternak kambing di Kota Surabaya. Pemeriksaan status kesehatan RPH Pegirian Surabaya terbatas pada kesehatan fisik, sedangkan pemeriksaan tentang infeksi cacing terutama Nematoda masih minim dilakukan, hal ini yang melatar belakangi penelitian. 


\section{Bahan dan Materi Penelitian}

Bahan penelitian adalah cacing untuk diwarnai dengan Carmine. Bahan yang diperlukan adalah $\mathrm{NaCl}$ fisiologis, larutan Carmine (asam asetat glasial dan carmine), alkohol 96\%, $\mathrm{HCl}, \mathrm{NaOH}$, aquadest, gliserin, larutan Hung's I dan Hung's II. Bedah omasum dan abomasum dibutuhkan tali, gunting bedah, saringan, pinset, nampan, petridish dan ember. Pada pewarnaan Semichen-Acetic Carmine dibutuhkan alat : stainning jar, object glass, cover glass, petridish dan mikroskop.

\section{Sampel dan Besar Sampel}

Sampel berupa omasum dan abomasum kambing kacang sejumlah 20 ekor dan kambing PE sejumlah 16 ekor dilaksanakan pada bulan September-November 2017, kemudian diberi label jenis hewan, dan tanggal pengambilan sampel (Mumpuni dkk., 2016).

\section{Koleksi cacing metode bedah saluran pencernaan}

Omasum dan abomasum yang diperoleh dari RPH dengan kedua ujungnya diikat, dibuka pada ujung omasum maupun abomasum, isinya diamati bila ada cacingnya diambil satu persatu dan diletakkan pada petridish yang telah diberi media $\mathrm{NaCl}$ fisiologis. Mukosa diamati bila terdapat cacing yang tertinggal, diambil menggunakan pinset dan diletakkan di petridish berisi $\mathrm{NaCl}$ fisiologis (Mumpuni dkk., 2016).

\section{Pewarnaan Semichen-Acetic Camine}

Pewarnaan berfungsi agar memudahkan identifikasi dan untuk mengawetkan preparat cacing agar tahan lama. Pewarnaan cacing metode Semichen-Acetic Camine (Kuhlmann, 2006). Cacing difiksasi di antara dua object glass dan diikat, dimasukkan alkohol gliserin $5 \% 24$ jam. Memasukkan ke dalam alkohol 70\% 5 menit, memindahkan ke dalam larutan Carmine \pm 8 jam. Cacing dilepas dari fiksasi dan dimasukkan ke dalam alkohol asam 2 menit, dipindahkan ke alkohol basa 20 menit. Dehidrasi bertingkat alkohol 70\%, alkohol 85\%, dan alkohol 95\% selama 5 menit, dilanjutkan mounting dalam larutan Hung's I 20 menit, cacing diletakkan pada object glass yang bersih dan diteteskan larutan Hung's II ditutup dengan cover glass. Bagian terakhir yaitu inkubator suhu $37^{\circ} \mathrm{C}$, dilanjutkan didinginkan pada suhu ruangan.

Data yang diperoleh dianalisis dengan menggunakan rumus prevalensi (Fuentes, dkk 2004). Untuk mengetahui adanya perbedaan prevalensi infeksi cacing nematoda omasum dan abomasum pada kambing kacang dan kambing PE dilakukan analisis statistik dengan menggunakan Statistical Package for the Social Science (SPSS) 22.0 for windows dengan menggunakan metode Chi-Square Test (Wibowo, 2002).

Prevalensi dihitung berdasarkan jumlah sampel terinfeksi dibanding jumlah populasi dan dinyatakan dalam persen.

\section{Hasil Penelitian}

Didapatkan jenis cacing Haemonchus contortus, sebagai kunci identifikasi menggunakan buku Penuntun Praktikum Helmintologi Veteriner (Koesdarto dkk, 2016), Buku Teks Helmintologi Kedokteran Hewan (Kusnoto dkk, 2014), serta Soulsby (1986).

Gambaran mikroskopik cacing Haemonchus contortus ditunjukkan bagian anterior (Gambar 1.); barber's pole cacing betina (Gambar 2.), posterior cacing betina disertai vulva flap (Gambar 3.), cacing jantan posterior beserta bursa kopulatrik (Gambar 4.).

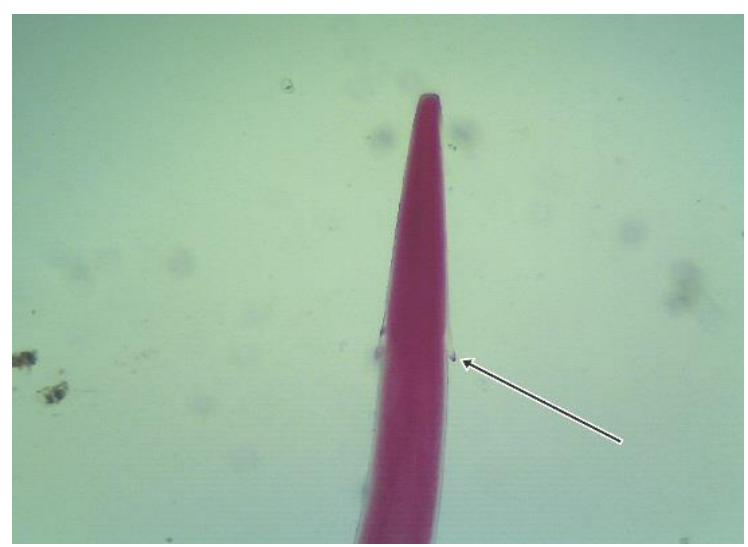

Gambar 1. Anterior cacing Haemonchus contortus (40x) dengan cervical papilae seperti duri. 


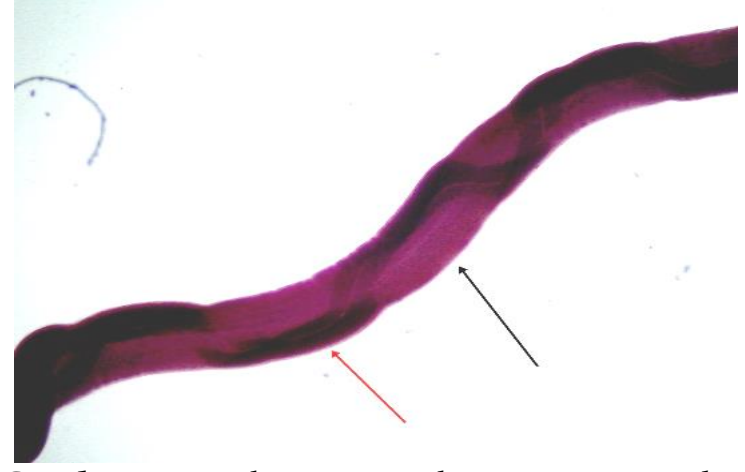

Gambar 2. Badan cacing betina Haemonchus contortus dengan pola barber'spole (40x), panah hitam daerah terang berupa uterus dan panah merah daerah gelap berupa intestine yang berisi darah.

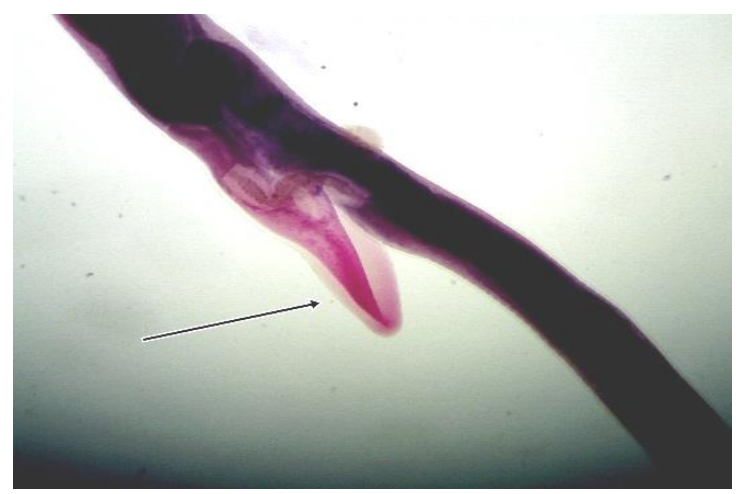

Gambar 3. Cacing betina Haemonchus contortus (40x), tanda panah menunjukkan vulva flap.

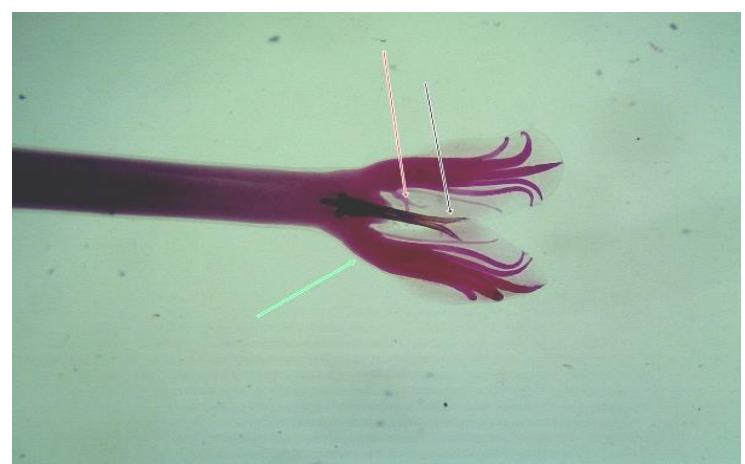

Gambar 4. Posterior cacing jantan Haemonchus contortus (100x), panah hitam spikula, panah merah dorsal rays menyerupai huruf $\mathrm{Y}$, panah hijau bursa kopulatrik, panah putih berupa gubernakulum.

17 sampel organ dinyatakan positif Haemonchus contortus dan 19 negatif dengan angka prevalensi sebesar $47,2 \%$, dari total cacing yang diperoleh sebanyak 273 ekor terdiri dari cacing betina 215 ekor $(78,75 \%)$ sedangkan cacing jantan sebesar 58 ekor (21,25\%). Hasil penelitian seperti terlihat pada Tabel 1 dan Tabel 2.

Tabel 1. Prevalensi Cacing yang Terdapat Pada Abomasum Kambing di RPH Pegirian Surabaya.

\begin{tabular}{lcc}
\hline \multicolumn{1}{c}{ Hasil } & Jumlah Sampel & $\begin{array}{c}\text { Presentase } \\
(\%)\end{array}$ \\
\hline Positif & 17 & 47,2 \\
Negatif & 19 & 52,8 \\
Total Sampel & 36 & 100 \\
\hline
\end{tabular}

Tabel 2. Data Jenis Kelamin Cacing yang Menginfeksi Kambing yang Dipotong di RPH Pegirian Surabaya.

\begin{tabular}{cc}
\hline Jenis Kelamin & Haemonchus contortus \\
\hline $0^{x}$ & $58(21,25 \%)$ \\
$\uparrow$ & $215(78,75 \%)$ \\
Total & 273 \\
\hline
\end{tabular}

Hasil positif ditemukan Haemonchus contortus pada kambing kacang 13 sampel (65\%), dan kambing PE 4 sampel (25\%). Hasil penelitian dapat dilihat pada Tabel 4.3.

Tabel 3. Hasil Pemeriksaan Cacing Haemonchus contortus yang Menginfeksi Kambing Kacang dan Kambing PE di RPH Pegirian Surabaya.

\begin{tabular}{|c|c|c|c|}
\hline \multirow{2}{*}{$\begin{array}{l}\text { Jenis } \\
\text { Kambing }\end{array}$} & \multicolumn{2}{|c|}{ Hasil Pemeriksaan } & \multirow{2}{*}{$\begin{array}{c}\text { Total } \\
\text { Sampel }\end{array}$} \\
\hline & Positif & Negatif & \\
\hline $\begin{array}{l}\text { Kambing } \\
\text { Kacang }\end{array}$ & $\begin{array}{c}13 \\
(65 \%)\end{array}$ & $7(35 \%)$ & 20 \\
\hline $\begin{array}{l}\text { Kambing } \\
\text { PE }\end{array}$ & $\begin{array}{c}4 \\
(25 \%) \\
\end{array}$ & $12(75 \%)$ & 16 \\
\hline
\end{tabular}

Analisis statistik chi-square menunjukkan angka $\mathrm{X}^{2}=5,71$ dan hasil signifikansi Pearson Chi-square didapatkan $\mathrm{P}$ value 0,017 dengan asumsi 0,017<0,05 yang berarti hasil berbeda signifikan maka terdapat pengaruh ras kambing terhadap infeksi Haemonchus contortus. 


\section{Pembahasan}

Identifikasi cacing dewasa secara mikroskopik pada bagian anterior memiliki cervical papilae yang menyerupai duri dan buccal cavity kecil dengan dorsal lancet. Cacing betina nampak pola berselang-seling merah putih (barber's pole) berupa uterus yang berwarna putih mengelilingi usus yang berisi darah berwarna merah, pada bagian posterior ujung meruncing dan tajam, terdapat vulva yang tertutup oleh vulva flap. Cacing jantan berwarna kemerahan, ujung posteriornya terdapat bursa kopulatrik besar yang terdiri dari tiga lobus dan ditopang oleh dorsal rays yang menyerupai huruf $\mathrm{Y}$. Spikula yang berukuran 0,46-0,506 $\mathrm{mm}$ masing-masing dilengkapi dengan duri kecil pada ujungnya dan mempunyai gubernakulum.

Haemonchosis merupakan penyakit yang disebabkan Haemonchus contortus dengan tingkat infeksinya mencapai $75 \%$ pada ternak ruminansia (Browning, 2006; Lastuti et al., 2006). Habitat cacing ini pada abomasum, biasanya dekat pylorus. Memiliki nama lain Stomach Worm, Barber's pole worm, atau Twisted wire worm (Dunn, 1978; Soulsby, 1986).

Mecistocirrus digitatus dan Haemonchus contortus merupakan cacing yang biasa ditemukan di abomasum, tetapi hasil $100 \%$ yang didapatkan Haemonchus contortus, hal ini menunjukkan adanya persaingan/kompetisi dari kedua genus cacing bersifat haematophagus. Wani et al., (2013) infeksi Haemonchus contortus mendominasi yaitu 50,90\% dibandingkan dengan Mecistocirrus digitatus. Emlen (1984) yang disitasi oleh Puspitawati (2001), tingginya infeksi Haemonchus contortus daripada Mecistocirrus digitatus merupakan bentuk kompetisi interspesies, berupa darah hospes menjadi perebutan.

Abomasum sebagai predisposisi haemonchosis disebabkan oleh karena struktur berupa lipatan yang memungkinkan kontak dengan pakan dalam jumlah besar (Umphrey dan Staples, 1992). Fungsional abomasum sebagai pencernaan enzimatis sehingga suasana $\mathrm{pH}$ asam memiliki korelasi dengan faktor yang mempengaruhi daya hidup Haemonchus contortus yang optimal hidup dalam suasana asam (Yuswandi dan Yuniar, 2015).

Perhitungan prevalensi sebesar $47,2 \%$, hasil ini lebih rendah dari hasil penelitian Kamaruddin (2001) untuk tingkatan infeksi cacing
Haemonchus contortus sebesar $87 \%$. Perbedaan ini disebabkan pengambilan sampel dilaksanakan pada musim kemarau. Total cacing Haemonchus contortus sebanyak 273 ekor, cacing betina 215 ekor $(78,75 \%)$, cacing jantan 58 ekor $(21,25 \%)$. Hal ini sependapat dengan penelitian yang Kamaruddin (2001) bahwa infeksi cacing betina lebih tinggi jumlahnya dibanding cacing jantan.

Hasil uji Chi-square menunjukkan bahwa terdapat pengaruh ras kambing terhadap infeksi Haemonchosis $(\mathrm{P}<0.05)$. 20 kambing kacang 13 ekor terinfeksi (65\%) dan 16 kambing PE 4 ekor terinfeksi (25\%). Devendra dan Burns (1994); Rostini dan Irwan (2017) morfologi anatomi mempengaruhi pola mencari makan, kambing PE memiliki struktur rahang brachinaghtia dengan kebiasaan mengangkat kepala saat mencari makan dan hijauan berupa dedaunan, sedangkan kambing kacang memiliki struktur rahang dan rahang bawah rata dengan kebiasaan menunduk saat memakan hijauan berupa rumput sehingga memberikan peluang tanah terbawa ke dalam saluran pencernaan dimana $\mathrm{L}_{3}$ banyak ditemukan di rumput. Balitbang Pertanian (2011), karakteristik kambing PE selektif pada keadaan bebas (digembalakan) serta mempunyai kemampuan untuk memilah saat merumput. Animut et al., (2005) menyatakan bahwa karakteristik kambing kacang yang dipelihara semi-intensif memberikan peluang lebih terkena infeksi haemonchosis, karena sifat cacing Haemonchus contortus ialah soil transmitted. Dhewiyanti, dkk (2015) intensitas larva infektif nematoda gastrointestinal pada feses kambing di RPH Kota Pontianak pada kambing kacang 16,22 (larva/gram/ekor) sedangkan PE lebih rendah 5 (larva/gram/ekor).

\section{Kesimpulan}

Cacing yang ditemukan Haemonchus contortus dengan angka prevalensi sebesar $47,2 \%$, dari total 273 infeksi cacing betina lebih tinggi yaitu 215 ekor $(78,75 \%)$ daripada cacing jantan 58 ekor $(21,25 \%)$. Analisis chi-square menunjukkan bahwa terdapat pengaruh ras kambing terhadap infeksi Haemonchus contortus, 20 kambing kacang dengan 13 ekor terinfeksi (65\%) lebih tinggi dibandingkan 16 kambing PE dengan 4 ekor terinfeksi (25\%). 


\section{Daftar Pustaka}

Andrade, C.T, I.A. Alava, D. Palacio, P.D. Poggio, C. Jamoletti, M. Guletta and A. Montressor. 2001. Prevalence and Intensity of Soil Transmitted Helminthiasis in the City of Portoviejo (Ecuador). Rio de Jeneiro. Vol 96 (8): 1075-1079.

Animut, G, A.I. Goetsch, G.E. Aiken, R. Puchala, G. Detweiler, C.R. Krehbiel, R.C. Merkel, T. Sahlu and L.J. Dawsin. 2005. Grazing Behavior and Energy Expenditure by Sheep and Goats Cograzing Grass Forb Pastures at Three Stocking Rates. Small Rumin Res. 59: 191- 201.

Badan Litbang Pertanian. 2011. [Internet] [Diunduh pada : 18 Desember 2017] http://www.litbang.pertanian.go.id/downloa d/one/142/file/KambingPeranakanEtawah.pdf.

Beriajaya and D.B. Copeman. 1997. An Estimate of Seasonality and Intensity of Infection with Gastrointestinal Nematodes in Sheep and Goats in West Java. Jurnal 1lmu Ternak dun Veteriner 2(4) :270-276.

Browning, M.L.L. 2006. Haemonchus contortus (Barber Pole Worm) Infestation in Goats. Extension Animal Scientist. Brazil (US): Alabama A \& M University Bandung.

Chalid, T, R.H. Matondang dan T. Herawati. 2011. Model Pembibitan Kambing dan Domba di Indonesia. Pusat Penelitian dan Pengembangan Peternakan.

Devendra dan Burns. 1994. Produksi Kambing di Daerah Tropis. Penerbit ITB.Bandung.

Dhewiyanti., V, T.R. Setyawati dan H.Y. Ari. 2015 Prevalensi dan Intensitas Larva Infektif Nematoda Gastrointestinal Strongylida dan Rhabditida pada Kultur Feses kambing (Capra sp.) di Tempat Pemotongan Hewan Kambing Pontianak. Protobiont (2015) Vol. 4 (1) : 178-183.

Dunn, A.M. 1978. Veterinary Helminthology. William Heinnemann Medical Books Ltd. London.

Fuentes, S.V., M. Saez, M. Trelis, C. Munos-atoli and G.J. Esteban. 2004. The Helmint Com- munity of Apodemus Sylvaticus (Rodentia, Muridae) in The Sierra de Gredos (Spain). Arxius de Miscel Idnia Zoologica 2:1-6. Sapain.

Kamaruddin, M. 2001. Studi Infeksi Haemonchus spp pada Kambing Kacang yang Dipotong di RPH Banda Aceh. Agripet Vol 2(2), Oktober 2001:18-21.

Koesdarto, S., S. Mumpuni dan Kusnoto. 2016. Penuntun Praktikum Helmintologi Veteriner. Fakultas Kedokteran Hewan Universitas Airlangga Surabaya.

Kuhlmann, W.F. 2006. Preservation, Staining, and Mounting Parasite Speciment. http://www.facstaff.unca.com. 24/12/2017.

Kusnoto, S. Subekti, S. Koesdarto dan S. M. Sosiawati, 2014. Buku Teks Helmintologi Kedokteran Hewan. Surabaya : Zifatama Publisher.

Lastuti, N.D.R., R. Kadek dan N.W. Ririen. 2006. Deteksi protein Haemonchus sp pada Domba dan Kambing dengan Uji Dot Blot Menggunakan Antibodi Poliklonal Protein 10 Ekskresi dan Sekresi Haemonchus contortus. Media Kedokteran Hewan. 22(3):162.

Levine N,D. 1990. Parasitologi Veteriner. Yogyakarta (ID): Gajah Mada University Press.

Mumpuni, S., S. Subekti, S. Koesdarto, H. Puspitawati dan Kusnoto. 2016 Penuntun Praktikum Ilmu Penyakit Helminth Veteriner. Fakultas Kedokteran Hewan Universitas Airlangga. Surabaya.

Puspitawati, H. 2006. Profil Morfologi Cacing Haemonchus contortus dan Mecistocirrus digitatus dengan Pewarnaan Carmine dan Scanning Electron Microscop (SEM). Thesis. Fakultas Kedokteran Hewan Universitas Airlangga.

Raza, M.A., H.A. Bachaya, M.S. Akhtar, H.M. Arshad, S. Murtaza, M.M. Ayaz, M. Najeem and A. Basit. 2012. Point Prevalence of Gastrointestinal Helminthiasis in Buffaloes (Bubalus bubalis) at The Vicinity of Jatoi. Punjab Pakistan. Science. Int. (Lahore). 24(4) : 465-69. 
Rostini, T. dan Irwan Z. 2017. Performans Produksi, Jumlah Nematoda Usus, dan Profil Metabolik Darah Kambing yang Diberi Pakan Hijauan Rawa Kalimantan. Jurnal Vet. Vol. 18 No. $3: 469-477$

Soulsby, E.J.L. 1982. Helminths, Arthropods, and Protozoa of Domesticated Animals. New York: Academic Press.

Umphrey, J.E. and C.R. Staples. 1992. General Anatomy of the Ruminant Digestive system. The Institute of Food and Agricultural Sciences is an Equal Opportunity.
Wani, Z.A., R.A. Shahardar and M.S. Maqbool. 2013. Prevalence of Nemathelminth Parasites in Locally Reared Sheep of Ganderbal District of Kashmir Valley based on Necropsy Examination. SKUAST-Kashmir Srinagar State of Jammu \& Kashmir.

Wibowo, E.S. 2002. Statistik Penelitian dan Aplikasinya dengan SPSS 10.0 for Windows. Penerbit Alfabeta Bandung.

Yuswandi dan S. Yuniar. 2015. Studi Biologi Larva dan Cacing Dewasa Hemonchus contortus pada Kambing. Balai Karantina Pertanian Kelas I Banjarmasin. JSV 33 (1). 